\title{
PENGARUH KOMPETENSI MANAJER PROYEK TERHADAP KEBERHASILAN PROYEK PADA PERUSAHAAN KONTRAKTOR DI KABUPATEN MALANG
}

\author{
Khusnul Prianto ${ }^{1}$, Sri Murni Dewi² \& Alwafi Pujiraharjo ${ }^{3}$ \\ ${ }^{1,2 \& 3}$ Fakultas Teknik Jurusan Teknik Sipil Universitas Brawijaya Malang \\ Alamat Korespondensi : Jl. MT. Haryono No 167 Malang, Indonesia \\ azdotagroup@yahoo.com
}

\begin{abstract}
This study aims to determine how big a role simultaneously and partially between knowledge, skills and attitude of the project manager to project success, and to know the most dominant factor that affects the success of a project. This research uses survey research conducted at contractor companies in Malang. The population in this study is the management of the contractor as the project manager supervisor leader contractor (director) or authorized by the company. Primary data was collected through questionnaires. Secondary data obtained from the literature to form iteratur, journals, and data from agencies with an interest in this study, such as professional associations and related agencies.

The results of descriptive analysis using respondents' answers showed knowledge variable, variable skills, attitudes and behavior / work commitment, top management variables on average have an important influence to determine the success of the project. Test results using regression analysis and test assumptions Multiple Linear Regression analysis shows simultaneously between the variables of knowledge, skills, work commitment and top management significantly influence the success of the project amounted to 0.831 . Partially between the variables of knowledge, skills, work commitment and top management significantly influence the success of the project amounted to $0.286,0.296,0.280$ and 0.147 .

Dominant variable affecting the level of success of a project is a skill / expertise.
\end{abstract}

Keywords: Competence, Project Manager, Contracting Company

\section{PENDAHULUAN}

Pembangunan infrastruktur yang dilakukan oleh pemerintah daerah pada akhir-akhir ini banyak menyisakan berbagai masalah yang berhubungan dengan tiga indikator yaitu mutu, biaya dan kualitas.

Pembangunan infrastruktur juga banyak dilakukan oleh pemerintah daerah, dalam hal ini Kabupaten Malang. Pada tahun 2011 Salah satu pembangunan tersebut adalah program rehabilitasi skala berat gedung sekolah dasar dan menengah yang tersebar di 33 kecamatan yang ada di Kabupaten Malang.

Dari pengamatan yang dilakukan di lapangan banyak terjadi pelaksanaan pekerjaan yang hanya dikelola oleh mandor bahkan ada beberapa yang langsung dikelola oleh tukang saja, sehingga pekerjaan yang dilakukan terkesan kurang terjadwal dengan baik. Jika dilihat dari nilai pekerjaan yang dilakukan seharusnya pekerjaan tersebut sudah harus benarbenar menerapkan sistem manajemen proyek, salah satunya yaitu dengan memiliki seorang manajer proyek yang memiliki kompetensi tinggi sehingga diharapkan akan tercapai keberhasilan pekerjaan tersebut ditinjau dari segi waktu, mutu, dan biaya yang telah dituangkan didalam kontrak.

Penelitian ini bertujuan untuk mengetahui Seberapa besar pengaruh secara stimultan dan pengaruh secara parsial antara knowledge/ pengetahuan, skill/ kemampuan dan sikap/ perilaku terhadap keberhasilan proyek, serta faktor dominan manakah yang mempengaruhi tingkat keberhasilan suatu proyek. 


\section{Manajemen Proyek}

Manajemen proyek adalah kombinasi personil, kebijakan, prosedur dan sistem (manual atau dengan kom-puter), yang memungkinkan terlaksananya kegiatan-kegiatan merencana-kan, mengorganisir, mengarahkan, dan mengendalikan biaya, jadwal, mutu, dan kinerja proyek". Manajemen proyek terdiri dari subsistem organisasi dan penge-lolaan hubungan antar manusia, serta pengelolaan aspek teknik (non manusia). Pengelolaan aspek teknik terdiri dari unsur-unsur sistem perencanaan, sistem pengendali-an, sistem metodologi dan sistem informasi manajemen (Love,et.el., 2003). Metode Simplek.

\section{Manajemen Sumber daya manusia}

Menurut Mohammad Agus Tulus (1993:2), manajemen sumber daya manusia adalah sumber daya yang paling penting dalam suatu organisasi untuk mencapai tujuan dimana bersama unsur yang lainnya seperti modal, bahan baku terkadang merupakan input yang dirubah melalui proses manajemen menjadi output yang berupa barang atau jasa dalam mencapi tujuan organisasi.

\section{Indikator Kinerja Manajer Proyek}

Menurut Syah (2004) ada tiga poin penting mengenai peranan manajer proyek dalam pengelolaan proyek:

1) Manajemen proyek tidak bisa dilakukan oleh sembarang orang karena manajer proyek, dalam menjalankan fungsi manajerialnya, memerlukan keahlian dan karakteristik tambahan di atas seperti apa yang biasa disyaratkan bagi manajer pabrik atau perusahaan lainnya. Demi keberhasilan proyek, peranan manajer proyek sangat penting dan mendasar. Hal ini terkait dengan misi besar yang dipertaruhkan dan dana yang harus dikelola dalam menyelesaikan sebuah proyek.

2) Manajer proyek yang baik tidak dilahirkan, tetapi dibentuk dan dijadikan. Manajer menjadi andal karena terlatih oleh pengalaman dalam menghadapi dan kesulitan yang timbul di tempat kerja. Mereka berkembang bukan hanya karena mempelajari catatan dan teori dari buku-buku, tetapi terutama karena hubungan kerja (relationship/team/ coordination) dengan mitra kerja atau mitra bisnis dan kemampuan dalam memecahkan berbagai macam persoalan yang ada. Meskipun demikian, mempelajari atau mendapatkan informasi dan keterampilan dari buku-buku yang mengupas/membahas manajemen proyek juga sangat bermanfaat sebagai persiapan menuju dunia kerja.

3) Mengingat peran penting seorang manajer proyek dan perlunya persyaratan yang berupa kemampuan khusus tersebut, maka banyak organisasi/institusi melihat hal itu sebagai peluang untuk melaksanakan program pelatihan manajemen bagi manajer proyek.

\section{Indikator Keberhasilan Pekerjaan}

Indikator performa proyek yang baik menurut Syah (2004) adalah ditinjau dari:

\section{Segi Biaya :}

- Sesuai dokumen kontrak dan kesepakatan.

- Pemilik proyek setuju dan melaksanakan pembayaran pekerjaan sampai selesai.

- Tidak terjadi progress billing tidak terbayar.

- Semua pihak terkait pelaksanaan proyek puas.

- Memperoleh manfaat positif termasuk keuntungan bagi perusahaan.

\section{Segi Mutu}

- Sesuai dokumen kontrak spesifikasi teknik, kesepakatan.

- Pemilik proyek setuju dan menerima proyek dengan tanpa komentar/ syarat tertentu.

- Tidak ada penalty, complain atau klaim atas mutu hasil kerja proyek.

- Keselamatan dan Kesehatan Kerja (K-3) dilaksanakan dengan baik.

- Semua pihak terkait pelaksanaan proyek puas.

- Memperoleh certificate of completion.

- Citra perusahaan baik.

\section{Segi Waktu}

- Sesuai jadwal kerja dokumen kontrak, kesepakatan. 
- Pemilik proyek setuju dan menerima selesainya sebagian dan atau keseluruhan pekerjaan yang bersangkutan.

- Tidak ada complain atau klaim dari pemberi kerja atau pihak ketiga yang terkait dengan penyelesaian pekerjaan tersebut.

- Semua pihak terkait pelaksanaan proyek puas.

- Citra perusahaan baik.

- Ada undangan dan atau penunjukan proyek baru.

\section{METODOLOGI PENELITIAN}

Penelitian ini dilakukan pada perusahaan kontraktor dengan kualifikasi non kecil dan kualifikasi kecil di Kabupaten Malang. Dari data yang didapat pada asosiasi pengusaha jasa konstruksi di kabupaten Malang dengan jumlah sekitar 80 perusahaan kontraktor.yang tergabung dalam asosiasi jasa kontruksiGAPENSI, GABPEKNAS, ASPEKINDO, AKSI,AKSINDO pada gred 2, 3, dan 4 engan populasi sasaran adalah pihak manajemen pada kontraktor selaku atasan manajer proyek yaitu pimpinan perusahaan kontraktor (direktur) atau yang diberi kuasa oleh pimpinan perusahaan.
Data primer dikumpulkan dari hasil jawaban kuesioner. Sedangkan data sekunder didapat dari hasil studi pustaka yang dapat berbentuk iteratur, jurnal, dan data-data dari lembaga yang berkepentingan dengan penelitian ini, seperti dari asosiasi profesi dan dinas terkait.

Uji Instrumen Penelitian dengan menggunakan uji validitas. Uji validitas adalah suatu ukuran yang menunjukkan tingkat-tingkat kevalidan dan kesahihan suatu instrument.

Uji reliabilitas menunjukkan tingkat kemantapan, keajegan dan ketepatan suatu alat ukur atau uji yang digunakan untuk mengetahui sejauh mana pengukuran relatif konsisten apabila dilakukan pengukuran ulang.

\section{HASIL DAN PEMBAHASAN}

\section{Analisis Deskriptif Jawaban Responden}

\section{Variabel Knowledge / Pengetahuan $\mathrm{X}_{1}$}

Persentase jawaban responden untuk variable knowledge dapat dilihat pada tabel 1.

Tabel 1. Skala Jawaban Untuk Variabel Knowledge/Pengetahuan $\mathrm{X}_{1}$

\begin{tabular}{|c|c|c|c|c|c|c|c|c|c|c|c|c|}
\hline \multirow{3}{*}{ Indikator } & \multirow{3}{*}{ Item } & \multicolumn{10}{|c|}{ Jawaban } & \multirow{3}{*}{ Rata-rata } \\
\hline & & \multicolumn{2}{|c|}{ STS } & \multicolumn{2}{|c|}{ TS } & \multicolumn{2}{|c|}{$\mathrm{N}$} & \multicolumn{2}{|r|}{$S$} & \multicolumn{2}{|c|}{ SS } & \\
\hline & & $\mathrm{f}$ & $\%$ & $\mathrm{f}$ & $\%$ & $\mathrm{f}$ & $\%$ & $\mathrm{f}$ & $\%$ & $\mathrm{f}$ & $\%$ & \\
\hline Latar & $\mathrm{X}_{1.1}$ & 0 & 0,0 & 2 & 2,5 & 32 & 40,0 & 21 & 26,3 & 25 & 31,3 & 3,86 \\
\hline Belakang & $\mathrm{X}_{1.2}$ & 0 & 0,0 & 0 & 0,0 & 31 & 38,8 & 24 & 30,0 & 25 & 31,3 & 3,92 \\
\hline \multirow{2}{*}{$\begin{array}{l}\text { Pendidian } \\
\left(\mathrm{X}_{1 \mathrm{a}}\right)\end{array}$} & $\mathrm{X}_{1.3}$ & 0 & 0,0 & 1 & 1,3 & 28 & 35,0 & 7 & 8,8 & 44 & 55,0 & 4,17 \\
\hline & $X_{1 \cdot 4}$ & 0 & 0,0 & 1 & 1,3 & 15 & 18,8 & 34 & 42,5 & 30 & 37,5 & 4,16 \\
\hline \multirow{4}{*}{$\begin{array}{l}\text { Pengalaman } \\
\text { Kerja }\left(\mathrm{X}_{1 \mathrm{~b}}\right)\end{array}$} & $X_{1.5}$ & 0 & 0,0 & 1 & 1,3 & 28 & 35,0 & 23 & 28,8 & 28 & 35,0 & 3,97 \\
\hline & $X_{1.6}$ & 0 & 0,0 & 0 & 0,0 & 23 & 28,8 & 18 & 22,5 & 39 & 48,8 & 4,20 \\
\hline & $\mathrm{X}_{1.7}$ & 0 & 0,0 & 4 & 5,0 & 26 & 32,5 & 18 & 22,5 & 32 & 40,0 & 3,97 \\
\hline & $\mathrm{X}_{1.8}$ & 0 & 0,0 & 0 & 0,0 & 34 & 42,5 & 25 & 31,3 & 21 & 26,3 & 3,84 \\
\hline \multirow{4}{*}{ Estimasi $\left(\mathrm{X}_{1 \mathrm{c}}\right)$} & $\mathrm{X}_{1.9}$ & 0 & 0,0 & 0 & 0,0 & 19 & 23,8 & 36 & 45,0 & 25 & 31,3 & 4,07 \\
\hline & $X_{1 \cdot 10}$ & 0 & 0,0 & 0 & 0,0 & 26 & 32,5 & 18 & 22,5 & 36 & 45,0 & 4,12 \\
\hline & $X_{1 \cdot 11}$ & 0 & 0,0 & 0 & 0,0 & 8 & 10,0 & 45 & 56,3 & 27 & 33,8 & 4,23 \\
\hline & $X_{1 \cdot 12}$ & 0 & 0,0 & 0 & 0,0 & 10 & 12,5 & 36 & 45,0 & 34 & 42,5 & 4,30 \\
\hline \multirow{4}{*}{$\begin{array}{l}\text { Merencanakan } \\
\text { Kualitas }\left(\mathrm{X}_{1 \mathrm{~d}}\right)\end{array}$} & $X_{1 \cdot 13}$ & 0 & 0,0 & 0 & 0,0 & 20 & 25,0 & 33 & 41,3 & 27 & 33,8 & 4,09 \\
\hline & $\mathrm{X}_{1 \cdot 14}$ & 0 & 0,0 & 0 & 0,0 & 23 & 28,8 & 18 & 22,5 & 39 & 48,8 & 4,20 \\
\hline & $X_{1 \cdot 15}$ & 0 & 0,0 & 0 & 0,0 & 24 & 30,0 & 14 & 17,5 & 42 & 52,5 & 4,22 \\
\hline & $X_{1 \cdot 16}$ & 0 & 0,0 & 0 & 0,0 & 20 & 25,0 & 26 & 32,5 & 34 & 42,5 & 4.17 \\
\hline
\end{tabular}




\begin{tabular}{|c|c|c|c|c|c|c|c|c|c|c|c|c|}
\hline & $\mathrm{X}_{1 \cdot 17}$ & 0 & 0,0 & 0 & 0,0 & 17 & 21,3 & 24 & 30,0 & 39 & 48,8 & 4,27 \\
\hline Organisasi & $X_{1 \cdot 18}$ & 0 & 0,0 & 0 & 0,0 & 19 & 23,8 & 22 & 27,5 & 39 & 48,8 & 4,25 \\
\hline \multirow[t]{2}{*}{ Proyek $\left(\mathrm{X}_{1 \mathrm{e}}\right)$} & $\mathrm{X}_{1 \cdot 19}$ & 0 & 0,0 & 0 & 0,0 & 22 & 27,5 & 11 & 13,8 & 47 & 58,8 & 4,31 \\
\hline & $X_{1 \cdot 20}$ & 0 & 0,0 & 0 & 0,0 & 6 & 7,5 & 34 & 42,5 & 40 & 50,0 & 4,42 \\
\hline \multirow{4}{*}{$\begin{array}{l}\text { Komunikasi } \\
\left(\mathrm{X}_{1 \mathrm{f}}\right)\end{array}$} & $\mathrm{X}_{1.21}$ & 0 & 0,0 & 0 & 0,0 & 25 & 31,3 & 15 & 18,8 & 40 & 50,0 & 4,19 \\
\hline & $X_{1.22}$ & 0 & 0,0 & 0 & 0,0 & 5 & 6,3 & 47 & 58,8 & 28 & 35,0 & 4,29 \\
\hline & $X_{1.23}$ & 0 & 0,0 & 0 & 0,0 & 12 & 15,0 & 39 & 48,8 & 29 & 36,3 & 4,21 \\
\hline & $X_{1.24}$ & 0 & 0,0 & 0 & 0,0 & 15 & 18,8 & 22 & 27,5 & 43 & 53,8 & 4,35 \\
\hline \multirow{3}{*}{ Resiko $\left(X_{1 \mathrm{~g}}\right)$} & $X_{1.25}$ & 0 & 0,0 & 0 & 0,0 & 25 & 31,3 & 16 & 20,0 & 39 & 48,8 & 4.17 \\
\hline & $X_{1.26}$ & 0 & 0,0 & 0 & 0,0 & 15 & 18,8 & 4 & 5,0 & 61 & 76,3 & 4,57 \\
\hline & $X_{1.27}$ & 0 & 0,0 & 0 & 0,0 & 15 & 18,8 & 13 & 16,3 & 51 & 65,0 & 4,46 \\
\hline \multirow{3}{*}{$\begin{array}{l}\text { Pengadaan } \\
\left(\mathrm{X}_{1 \mathrm{~h}}\right)\end{array}$} & $X_{1.28}$ & 0 & 0,0 & 0 & 0,0 & 27 & 33,8 & 33 & 41,3 & 20 & 25,0 & 3,91 \\
\hline & $X_{1.29}$ & 0 & 0,0 & 0 & 0,0 & 27 & 33,8 & 27 & 33,8 & 26 & 32,5 & 3,99 \\
\hline & $X_{1 \cdot 30}$ & 0 & 0,0 & 0 & 0,0 & 13 & 16,3 & 18 & 22,5 & 49 & 61,3 & 4,45 \\
\hline
\end{tabular}

Sumber : Data Primer diolah 2012

\section{- Indikator Latar Belakang Pendidikan}

Dari tabel 1. diketahui mayoritas responden menjawab sangat setuju jika latar belakang pendidikan manajer proyek setara sarjana (S1). Hal ini disebabkan manajer sebagai pengawas sekaligus pimpinan proyek memiliki peran penting dalam kesuksesaan proyek, manajer yang memiliki latar belakang pendidikan formal yang cukup baik, minimal sarjana diharapkan memiliki kemampuan teoritis terkait pelaksanaan proyek yang nantinya mampu mengaplikasikan ilmu yang didapatkan secara nyata di lapangan. Pendidikan berpengaruh terhadap kompetensi khusus, dimana seseorang meguasai bidang keahlian yang dipelajari secara mendalam. (Wibowo\&Fandi,2009). Adapun grafik persentase jawaban responden berdasarkan indikator latar belakang pendidikan dapat dilihat pada gambar 1.

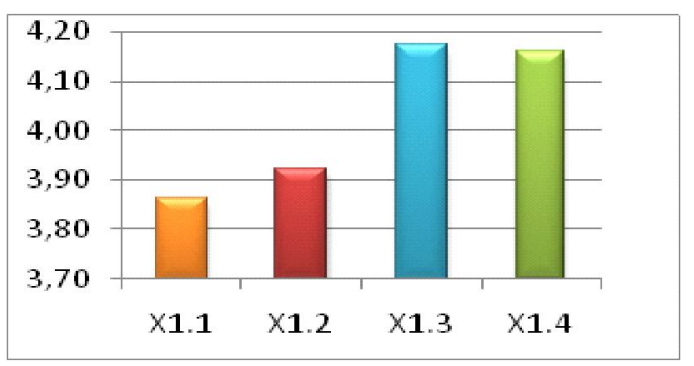

Gambar 1. Grafik Persentase Jawaban Responden Berdasarkan Indikator Latar Belakang

\section{- Indikator Pengalaman Kerja}

Dari tabel 1. diketahui bahwa mayoritas responden menjawab sangat setuju jika pengalaman kerja penting untuk seorang manajer proyek. Pengalaman kerja menjadi suatu nilai lebih seorang manajer. Keunikan suatu proyek konstruksi adalah tidak pernah ada yang sama persis baik dari segi fisik, manajemen maupun hasil akhir. Seorang manajer yang berpengalaman tentu pernah mengalami berbagai permasalahan dalam konstruksi yang pernah ditanganinya dan harus mampu memberikan solusi dari masalah tersebut.

Adapun grafik persentase jawaban responden berdasarkan indikator pengalaman kerja dapat dilihat pada gambar 2 .

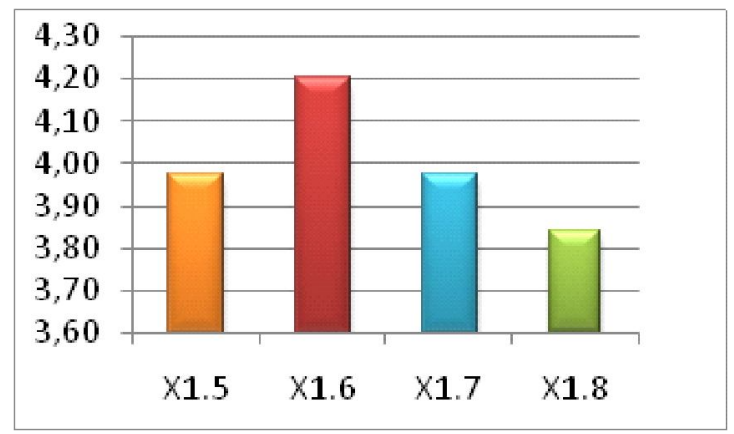

Gambar 2. Grafik Persentase Jawaban Responden Berdasarkan Indikator Pengalaman Kerja 


\section{- Indikator Estimasi}

Dari tabel 1. diketahui mayoritas responden setuju jika seorang manajer proyek perlu melakukan estimasi dalam pekerjaannya. Estimasi adalah perkiraan, Dalam proyek, estimasi dapat dikaitkan dengan biaya dan waktu. Estimasi biaya pada proyek biasanya memberikan indikasi tertentu terhadap total biaya proyek. Seorang manajer proyek harus mampu mengestimasi biaya pelaksanaan proyek, karena estimasi biaya berperan penting terhadap keberhasilan proyek. kualitas estimasi proyek tergantung pada tersedianya data dan informasi, teknik atau metode yang digunakan, kecakapan serta pengalaman manajer proyek (Dipohusodo, 1999). Adapun grafik persentase jawaban responden berdasarkan indikator estimasi dapat dilihat pada gambar 3.

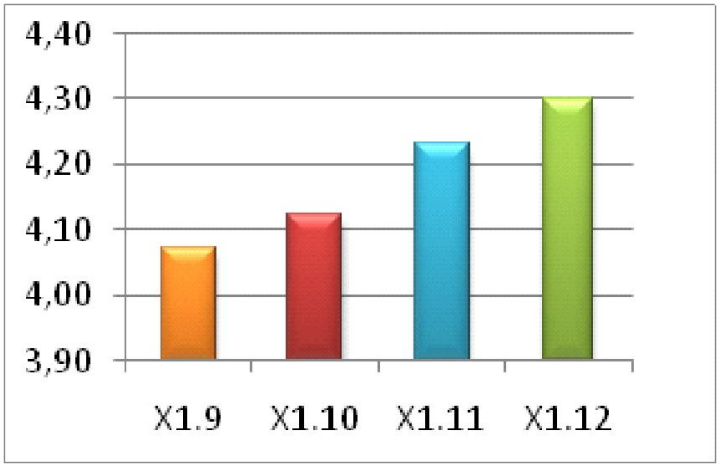

Gambar 3. Grafik Persentase Jawaban Responden Berdasarkan Indikator Estimasi

\section{- Indikator Merencanakan Kualitas}

Dari tabel 1. diketahui mayoritas responden sangat setuju jika seorang manajer proyek perlu merencanakan kualitas pekerjaannya. Dalam pelaksanaan proyek konstruksi, perencanaan kualitas adalah strategi pencapaian mutu, biaya dan waktu proyek. manajer. Sebagai seorang menejer proyek, perencanaan kualitas proyek dimulai dari awal, pelaksanaan hingga akhir proyek. salah satu hal penting misalnya perencanaan yang berkaitan terhadap pengawasan para mandor ataupun subkontraktor dalam hal pencampuran bahan yang digunakan, karena bahan merupakan item penting dalam penentuan kualitas konstruksi. Adapun grafik persentase jawaban responden berdasarkan indikator merencanakan kualiatas dapat dilihat pada gambar 4.4.

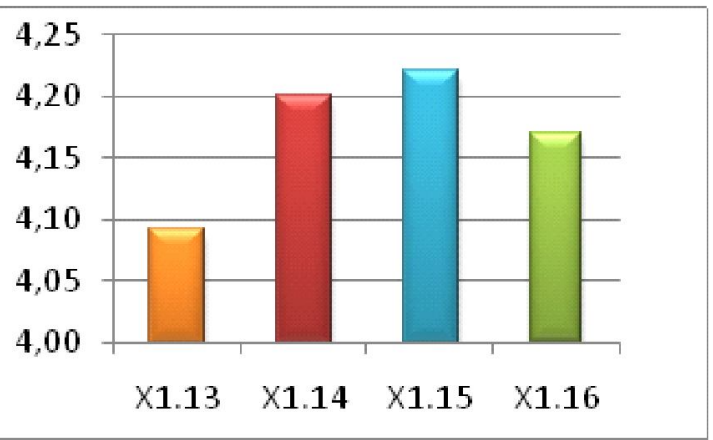

Gambar 4. Grafik Persentase Jawaban Responden Berdasarkan Indikator Merencanakan Kualitas

\section{- Indikator Organisasi Proyek}

Dari tabel 1. diketahui mayoritas responden sangat setuju jika seorang manajer proyek perlu melakukan organisasi proyek. Manajer proyek dalam melaksanakan tugasnya sudah pasti akan melakukan banyak interaksi baik dengan pemilik proyek, pimpinan ataupun para pekerja, mandor, tukang untuk itu diperlukan kemamampuan berorganisasi yang baik. Organisasi proyek juga dibutuhkan untuk memastikan bahwa pekerjaan dapat diselesaikan dengan cara yang efisien, tepat waktu dan sesuai dengan kualitas yang diharapkan. Adapun grafik persentase jawaban responden berdasarkan indikator organisasi proyek dapat dilihat pada gambar 5 .

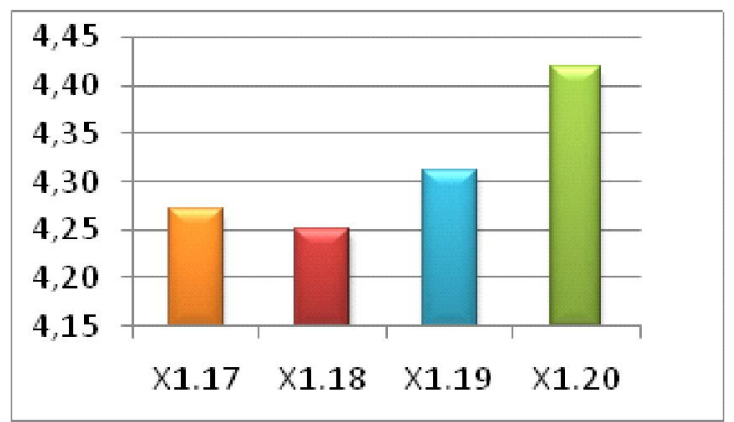

Gambar 5. Grafik Persentase Jawaban Responden Berdasarkan Indikator Organiesasi Proyek

\section{- Indikator Komunikasi}

Dari tabel 1. diketahui mayoritas responden sangat setuju jika komunikasi penting bagi 
seorang manajer proyek. Pengaruh manajer proyek sangat dominan terhadap keberhasilan kinerja proyek. Manajer proyek meluangkan $90 \%$ waktunya untuk berkomunikasi kepada team proyek, customer dan Owner. Dengan demikian kemampuan komunikasi manajer proyek akan sangat mempengaruhi kinerja proyek. Setiap orang yang terlibat dalam pelaksanaan proyek harus memahami bagaimana komunikasi dapat mempengaruhi kinerja proyek secara keseluruhan. Pemahaman manajemen komunikasi dalam pelaksanaan proyek merupakan suatu hal yang penting sebab seberapapun hebatnya suatu perencanaan tanpa dikomunikasikan secara terstruktural maka tidak akan tercapai tujuan akhir dari perencanaan tersebut (Prajogo, 2010). Adapun grafik persentase jawaban responden berdasarkan indikator komunikasi dapat dilihat pada gambar 6.

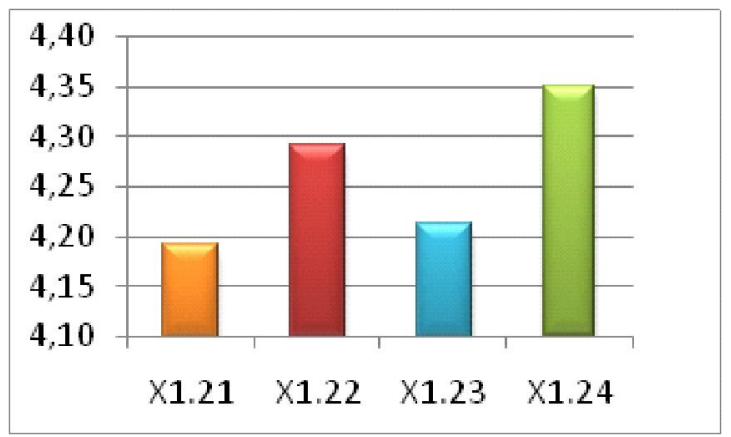

Gambar 6. Grafik Persentase Jawaban Responden Berdasarkan Indikator Komunikasi

\section{- Indikator Resiko}

Dari tabel 1. diketahui mayoritas responden sangat setuju jika seorang manajer proyek harus bertanggung jawab atas semua resiko yang terjadi dalam pekerjaannya. Dalam proyek konstruksi baik gedung maupun infrastruktur sangat rentan terhadap resiko. Setiap manajer proyek harus mengetahui jobdesk, tanggung jawab serta resiko proyek yang akan ditanganinya. Dan dalam tahap pelaksanaan apabila terjadi masalah, manajer proyek harus mampu dan tanggap untuk memberikan solusi yang teat guna menyelesaikan proyek sesuai dengan mutu, biaya dan waktu. Adapun grafik persentase jawaban responden dapat dilihat pada gambar 7.

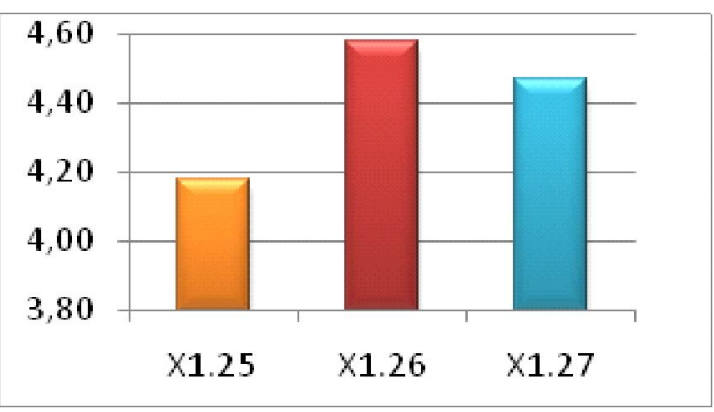

Gambar 7. Grafik Persentase Jawaban Responden Berdasarkan Indikator Resiko

\section{- Indikator Pengadaan}

Dari tabel 1. diketahui mayoritas responden setuju jika seorang manajer proyek harus mengadakan pengadaan baik material maupun admnistrasi untuk pekerjaannya. Pengadaan material, proses administrasi dalam proyek membutuhkan ketelitian, karena material berkaitan dengan budget dan kualitas konstruksi. Manajer proyek dituntut harus mampu memanage material yang tepat baik pengadaan, penggunaan dan pemeliharaan serta membuat list untuk kebutuhan dan report jumlah material yang habis pakai. Adapun grafik persentase jawaban responden dapat dilihat pada gambar 8 .

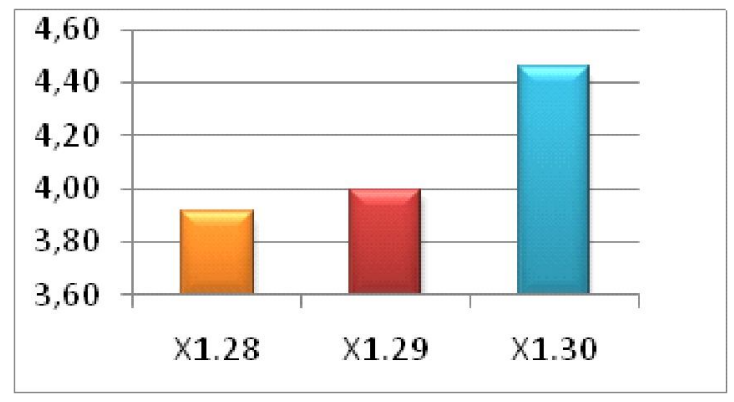

\section{Gambar 8. Grafik Persentase Jawaban Responden Berdasarkan Indikator Pengadaan}

\section{Variabel Skill/Keahlian}

Hasil diskriptif jawaban kuesioner oleh responden untuk variable skill/keahlian dapat dilihat pada tabel .1 . 
Tabel 2. Analisis diskriptif variable skill / keahlian $X_{2}$

\begin{tabular}{cl}
\hline $\begin{array}{c}\text { Indikator } \\
\text { Variabel Skill / } \\
\text { Keahlian X2 }\end{array}$ & \multicolumn{1}{c}{$\begin{array}{c}\text { JawabanMayoritas Responden } \\
\text { Berdasarkan Analisis Diskriptif }\end{array}$} \\
\hline Prediksi X2.a & $\begin{array}{l}\text { Sangat Setuju jika seorang manajer proyek } \\
\text { harus mempunyai keahlian dalam memprediksi } \\
\text { segala macam yang berhubungan dengan } \\
\text { pekerjaannya }\end{array}$ \\
Berpengaruh X2.b & $\begin{array}{l}\text { Sangat Setuju jika seorang manajer proyek } \\
\text { harus mempunyai pengaruh dan bisa } \\
\text { mempengaruhi semua elemen dalam } \\
\text { organisasi proyek }\end{array}$ \\
Mengambil & $\begin{array}{l}\text { Sangat Setuju jika seorang manajer proyek } \\
\text { harus mampu mengambil keputusan serta } \\
\text { mampu mencari solusi yang terbaik disetiap } \\
\text { permasalahan yang dihadapinya }\end{array}$ \\
Kerjasama X2.d & $\begin{array}{l}\text { Sangat Setuju jika seorang manajer proyek } \\
\text { harus mempunyai keahlian dalam bekerjasama } \\
\text { baik dengan bawahan maupun relasi lainnya } \\
\text { Sangat Setuju jika seorang manajer proyek } \\
\text { perlu keahlian dari aspek teknis dalam } \\
\text { menunjang pekerjaannya }\end{array}$ \\
Aspek TeknisX2.e & $\begin{array}{l}\text { Sangat Setuju pada variabel tersebut jika } \\
\text { seorang manajer memiliki penguasaan } \\
\text { terhadap teknologi }\end{array}$ \\
\hline
\end{tabular}

Tabel 3. Skala Jawaban Untuk Variabel Skill / Keahlian $\mathrm{X}_{2}$

\begin{tabular}{|c|c|c|c|c|c|c|c|c|c|c|c|c|}
\hline \multirow{3}{*}{ Indikator } & \multirow{3}{*}{ Item } & \multicolumn{10}{|c|}{ Jawaban } & \multirow{3}{*}{ Rata-rata } \\
\hline & & \multicolumn{2}{|c|}{ STS } & \multicolumn{2}{|c|}{ TS } & \multicolumn{2}{|c|}{$\mathrm{N}$} & \multicolumn{2}{|c|}{$S$} & \multicolumn{2}{|c|}{ SS } & \\
\hline & & $\mathrm{f}$ & $\%$ & $\mathrm{f}$ & $\%$ & $f$ & $\%$ & $\mathrm{f}$ & $\%$ & $\mathrm{f}$ & $\%$ & \\
\hline \multirow{4}{*}{$\begin{array}{l}\text { Prediksi } \\
\left(\mathrm{X}_{2 \mathrm{a}}\right)\end{array}$} & $\mathrm{X}_{2.1}$ & 0 & 0,0 & 0 & 0,0 & 25 & 31,3 & 27 & 33,8 & 28 & 35,0 & 4,03 \\
\hline & $\mathrm{X}_{2.2}$ & 0 & 0,0 & 0 & 0,0 & 25 & 31,3 & 24 & 30,0 & 31 & 38,8 & 4,07 \\
\hline & $\mathrm{X}_{2.3}$ & 0 & 0,0 & 0 & 0,0 & 23 & 28,8 & 17 & 21,3 & 40 & 50,0 & 4,21 \\
\hline & $\mathrm{X}_{2.4}$ & 0 & 0,0 & 0 & 0,0 & 14 & 17,5 & 40 & 50,0 & 26 & 32,5 & 4,15 \\
\hline \multirow{3}{*}{$\begin{array}{l}\text { Berpengaruh } \\
\left(\mathrm{X}_{2 \mathrm{~b}}\right)\end{array}$} & $\mathrm{X}_{2.5}$ & 0 & 0,0 & 0 & 0,0 & 25 & 31,3 & 34 & 42,5 & 21 & 26,3 & 3,95 \\
\hline & $\mathrm{X}_{2.6}$ & 0 & 0,0 & 0 & 0,0 & 25 & 31,3 & 27 & 33,8 & 28 & 35,0 & 4,04 \\
\hline & $\mathrm{X}_{2.7}$ & 0 & 0,0 & 0 & 0,0 & 27 & 33,8 & 21 & 26,3 & 32 & 40,0 & 4,06 \\
\hline \multirow{2}{*}{$\begin{array}{l}\text { Mengambil } \\
\text { Keputusan } \\
\left(\mathrm{X}_{2 \mathrm{c}}\right) \\
\end{array}$} & $\mathrm{X}_{2.8}$ & 0 & 0,0 & 0 & 0,0 & 23 & 28,8 & 23 & 28,8 & 34 & 42,5 & 4,14 \\
\hline & $\mathrm{X}_{2.9}$ & 0 & 0,0 & 0 & 0,0 & 23 & 28,8 & 28 & 35,0 & 29 & 36,3 & 4,07 \\
\hline \multirow{3}{*}{$\begin{array}{l}\text { Kerjasama } \\
\left(\mathrm{X}_{2 \mathrm{~d}}\right)\end{array}$} & $\mathrm{X}_{2.10}$ & 0 & 0,0 & 0 & 0,0 & 22 & 27,5 & 17 & 21,3 & 41 & 51,3 & 4,23 \\
\hline & $\mathrm{X}_{2.11}$ & 0 & 0,0 & 0 & 0,0 & 30 & 37,5 & 20 & 25,0 & 30 & 37,5 & 4,00 \\
\hline & $\mathrm{X}_{2.12}$ & 0 & 0,0 & 0 & 0,0 & 3 & 3,8 & 43 & 53,8 & 34 & 42,5 & 4,39 \\
\hline \multirow{4}{*}{$\begin{array}{l}\text { Aspek } \\
\text { Teknis }\left(\mathrm{X}_{2 \mathrm{e}}\right)\end{array}$} & $\mathrm{X}_{2.13}$ & 0 & 0,0 & 0 & 0,0 & 30 & 37,5 & 15 & 18,8 & 35 & 43,8 & 4,06 \\
\hline & $\mathrm{X}_{2.14}$ & 0 & 0,0 & 0 & 0,0 & 24 & 30,0 & 16 & 20,0 & 40 & 50,0 & 4,20 \\
\hline & $\mathrm{X}_{2.15}$ & 0 & 0,0 & 0 & 0,0 & 24 & 30,0 & 17 & 21,3 & 39 & 48,8 & 4,19 \\
\hline & $X_{2.16}$ & 0 & 0,0 & 0 & 0,0 & 22 & 27,5 & 34 & 42,5 & 24 & 30,0 & 4,02 \\
\hline
\end{tabular}




\begin{tabular}{lcccccccccccc}
\hline $\begin{array}{l}\text { Penguasaan } \\
\text { Teknologi }\end{array}$ & $\mathrm{X}_{2.17}$ & 0 & 0,0 & 0 & 0,0 & 32 & 40,0 & 16 & 20,0 & 33 & 40,0 & 4,00 \\
$\left(\mathrm{X}_{2 \mathrm{f}}\right)$ & $\mathrm{X}_{2.18}$ & 0 & 0,0 & 0 & 0,0 & 13 & 16,3 & 38 & 47,5 & 29 & 36,3 & 4,20 \\
\hline & \multicolumn{10}{c}{$\mathrm{X}_{2}$} \\
\hline
\end{tabular}

Variabel Sikap dan Perilaku/ Komitmen kerja $X_{3}$

Hasil diskriptif jawaban kuesioner oleh responden untuk variable sikap/perilaku dapat dilihat pada tabel .2 .

Tabel 4. Analisis diskriptif variable Sikap dan Perilaku

\begin{tabular}{ll}
\hline $\begin{array}{l}\text { Indikator Variabel Sikap dan } \\
\text { Perilaku }\end{array}$ & \multicolumn{1}{c}{ JawabanMayoritas Responden Berdasarkan Analisis Diskriptif } \\
\hline $\begin{array}{l}\text { BekerjaKeras } \\
\text { X3.a }\end{array}$ & $\begin{array}{l}\text { Sangat Setuju jika seorang manajer proyek harus bekerja keras dalam } \\
\text { menyelesaikan pekerjaannya }\end{array}$ \\
Percaya Diri X3.b & $\begin{array}{l}\text { Sangat Setuju jika seorang manajer proyek harus mempunyai percaya } \\
\text { diri yang baik dalam melaksanakan tanggung jawabnya }\end{array}$ \\
EtosKerja X3.c & $\begin{array}{l}\text { Setuju jika seorang manajer proyek harus mempunyai etos kerja yang } \\
\text { baik. }\end{array}$ \\
Obyektif X3.d & $\begin{array}{l}\text { Setuju jika seorang manajer proyek mempunyai sikap yang obyektif } \\
\text { dalam mengahapi permasalahan }\end{array}$ \\
Tanggung Jawab & Sangat Setuju jika seorang manajer proyek memiliki tanggung jawab \\
X3.e & terhadap tugasnya \\
\hline
\end{tabular}

Tabel 5. Skala Jawaban Untuk Variabel Perilaku/Komitmen Kerja $X_{3}$

\begin{tabular}{|c|c|c|c|c|c|c|c|c|c|c|c|}
\hline \multirow{3}{*}{ Indikator } & \multirow{3}{*}{ Item } & \multicolumn{9}{|c|}{ Jawaban } & \multirow{3}{*}{ Rata-rata } \\
\hline & & \multicolumn{2}{|c|}{$\mathrm{TP}$} & \multicolumn{2}{|c|}{$\mathrm{J}$} & \multicolumn{2}{|c|}{ KK } & \multicolumn{2}{|c|}{ SR } & SL & \\
\hline & & $\mathrm{f}$ & $\%$ & $\mathrm{f}$ & $\%$ & $f$ & $\%$ & $f$ & $\%$ & f $\%$ & \\
\hline Bekerja & $\mathrm{X}_{3.1}$ & 0 & 0,0 & 0 & 0,0 & 31 & 38,8 & 17 & 21,3 & 3240,0 & 4,01 \\
\hline $\operatorname{Keras}\left(\mathrm{X}_{3 \mathrm{a}}\right)$ & $X_{3.2}$ & 0 & 0,0 & 0 & 0,0 & 25 & 31,3 & 23 & 28,8 & 3240,0 & 4,08 \\
\hline \multirow{4}{*}{$\begin{array}{c}\text { Percaya } \\
\text { Diri }\left(\mathrm{X}_{3 \mathrm{~b}}\right)\end{array}$} & $\mathrm{X}_{3 \cdot 3}$ & 0 & 0,0 & 0 & 0,0 & 25 & 31,3 & 16 & 20,0 & 3948,8 & 4,17 \\
\hline & $X_{3 \cdot 4}$ & 0 & 0,0 & 0 & 0,0 & 25 & 31,3 & 22 & 27,5 & 3341,3 & 4,10 \\
\hline & $X_{3.5}$ & 0 & 0,0 & 0 & 0,0 & 27 & 33,8 & 21 & 26,3 & 3240,0 & 4,06 \\
\hline & $\mathrm{X}_{3.6}$ & 0 & 0,0 & 0 & 0,0 & 24 & 30,0 & 13 & 16,3 & 4353,8 & 4,24 \\
\hline \multirow{3}{*}{$\begin{array}{l}\text { Etos Kerja } \\
\qquad\left(\mathrm{X}_{3 \mathrm{c}}\right)\end{array}$} & $\mathrm{X}_{3 \cdot 7}$ & 0 & 0,0 & 0 & 0,0 & 1 & 1,3 & 46 & 57,5 & 3341,3 & 4,40 \\
\hline & $\mathrm{X}_{3.8}$ & 0 & 0,0 & 0 & 0,0 & 33 & 41,3 & 23 & 28,8 & 2430,0 & 3,88 \\
\hline & $\mathrm{X}_{3.9}$ & 0 & 0,0 & 0 & 0,0 & 27 & 33,8 & 26 & 32,5 & 2733,8 & 4,00 \\
\hline \multirow{3}{*}{$\begin{array}{c}\text { Obyektif } \\
\left(\mathrm{X}_{3 \mathrm{~d}}\right)\end{array}$} & $X_{3.10}$ & 0 & 0,0 & 0 & 0,0 & 14 & 17,5 & 45 & 56,3 & 2126,3 & 4,09 \\
\hline & $\mathrm{X}_{3.11}$ & 0 & 0,0 & 0 & 0,0 & 24 & 30,0 & 46 & 57,5 & $10 \quad 12,5$ & 3,82 \\
\hline & $X_{3.12}$ & 0 & 0,0 & 0 & 0,0 & 26 & 32,5 & 22 & 27,5 & 3240,0 & 4,07 \\
\hline \multirow{3}{*}{$\begin{array}{c}\text { Tanggung } \\
\text { Jawab }\left(\mathrm{X}_{3 \mathrm{e}}\right)\end{array}$} & $\mathrm{X}_{3.13}$ & 0 & 0,0 & 0 & 0,0 & 24 & 30,0 & 35 & 43,8 & 2126,3 & 3,96 \\
\hline & $X_{3 \cdot 14}$ & 0 & 0,0 & 0 & 0,0 & 30 & 37,5 & 16 & 20,0 & 3442,5 & 4,05 \\
\hline & $X_{3.15}$ & 0 & 0,0 & 0 & 0,0 & 1 & 1,3 & 37 & 46,3 & 4353,8 & 4,52 \\
\hline \multicolumn{11}{|c|}{$\mathrm{X}_{3}$} & 4,09 \\
\hline
\end{tabular}

Variabel Top Managemen $\mathrm{X}_{4}$

Hasil diskriptif jawaban kuesioner oleh responden untuk variable top managemen dapat dilihat pada tabel 6. 
Tabel 6. Analisis diskriptif variable Top

\begin{tabular}{ll}
\hline $\begin{array}{l}\text { Indikator Variabel Top } \\
\text { Manajemen }\end{array}$ & JawabanMayoritas Responden Berdasarkan Analisis Diskriptif \\
\hline Pendanaan X4.a & mayoritas responden berharap indicator pendanaan proyek lancar \\
Peralatan X4.b & mayoritas responden berharap indicator peralatan proyek lancar \\
Material X4.c & mayoritas responden perharap indikator Material proyek lancar \\
Insentif X4.d & mayoritas responden perharap indikator Insentif proyek lancar \\
\hline
\end{tabular}

\section{Uji Asumsi Analisis Regresi}

\section{- Pengujian Asumsi Normalitas}

Model regresi dapat dikatakan memenuhi asumsi normalitas jika residual yang disebabkan oleh model regresi berdistribusi normal. Untuk menguji asumsi ini, dapat digunakan metode Kolmogorov-Smirnov.

Hipotesis :

Ho :Distribusi populasi yang diwakili oleh sampel berdistribusi normal

H1 :Distribusi populasi yang diwakili oleh sampel tidak berdistribusi normal
Tabel 7. Uji Asumsi Normalitas

\begin{tabular}{ccc}
\hline Statistik Uji & Nilai & Keterangan \\
\hline $\begin{array}{c}\text { Kolmogorov- } \\
\text { Smirnov Z }\end{array}$ & 0,880 & $\begin{array}{c}\text { Menyebar } \\
\text { Normal }\end{array}$ \\
\cline { 1 - 2 } Signifikan & 0,421 & \\
\hline
\end{tabular}

Berdasarkan pengujian Kolmogorov-Smirnov di atas, didapatkan nilai signifikan sebesar 0,421, dimana nilai tersebut lebih besar daripada $a ́=0,05$. Karena nilai signifikansi lebih besar daripada $a ́=0,05$, maka Ho diterima sehingga dapat disimpulkan bahwa asumsi normalitas residual terpenuhi.

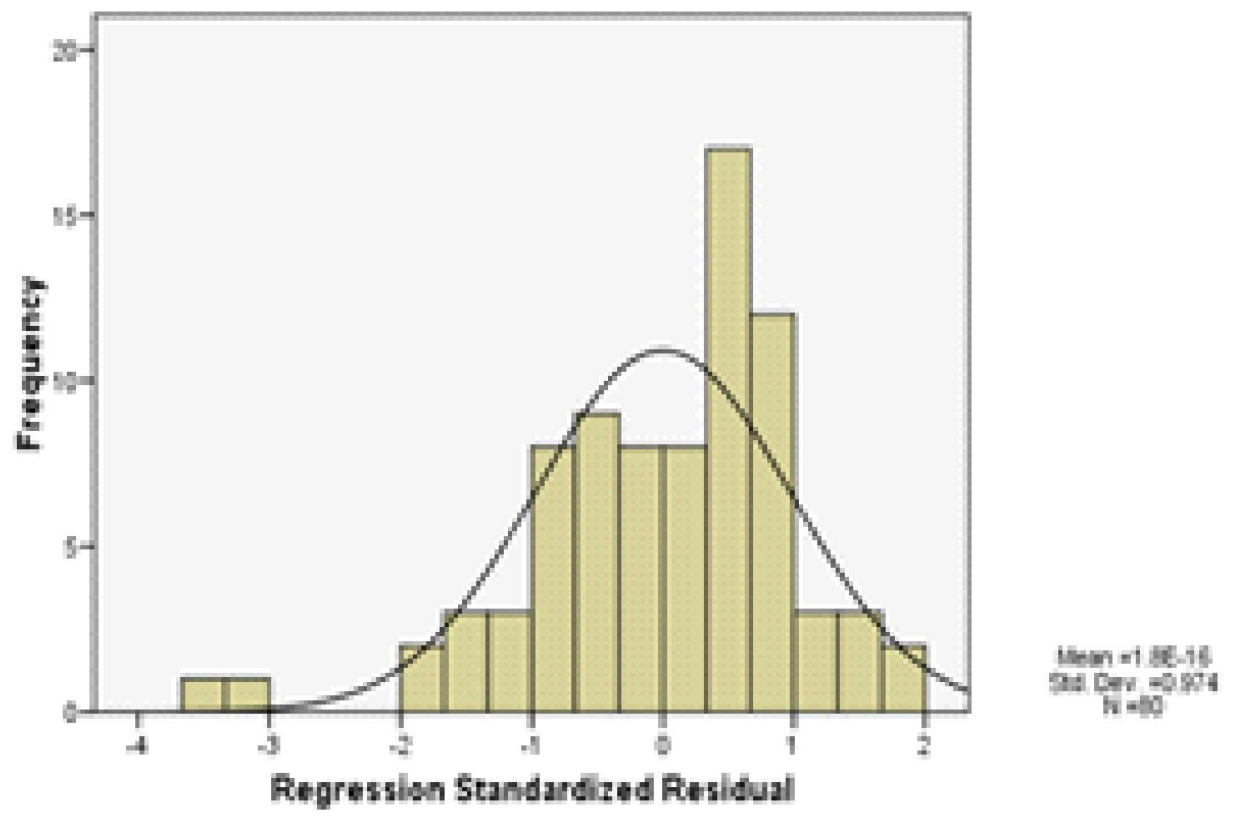

\section{Gambar 9. Histogram Uji Asumsi Normalitas}

\section{Pengujian Asumsi Multikolinieritas}

Untuk mendeteksi ada atau tidaknya multikolinieritas dapat dilihat dari Variance Inflation
Factor (VIF). Apabila nilai VIF $>10$ maka menunjukkan adanya multikolinieritas. Dan apabila sebaliknya VIF < 10 maka tidak terjadi multikolinieritas. 
Tabel 8. Uji multikolinieritas

\begin{tabular}{ccl}
\hline $\begin{array}{c}\text { Variabel } \\
\text { Independen }\end{array}$ & VIF & Keterangan \\
\hline $\mathrm{X}_{1}$ & 6,339 & $\begin{array}{l}\text { Non } \\
\text { Multikolinier }\end{array}$ \\
$\mathrm{X}_{2}$ & 5,981 & $\begin{array}{l}\text { Non } \\
\text { Multikolinier }\end{array}$ \\
$\mathrm{X}_{3}$ & 5,038 & $\begin{array}{l}\text { Non } \\
\text { Multikolinier }\end{array}$ \\
& & $\begin{array}{l}\text { Non } \\
\text { Multikolinier }\end{array}$ \\
\hline
\end{tabular}

Dari hasil perhitungan yang ada di Tabel 10 masing-masing variabel bebas menunjukkan nilai VIF yang tidak lebih dari nilai 10 , maka asumsi tidak terjadi multikolinieritas telah terpenuhi.

\section{Pengujian Asumsi Heteroskedastisitas}

Heteroskedastisitas dapat dideteksi dengan melihat grafik plot antara nilai prediksi variabel terikat (dependen) yaitu ZPRED dengan residualnya SRESID. Deteksi ada tidaknya heteroskedastisitas dapat dilakukan dengan melihat ada tidaknya pola tertentu pada grafik scatterplot antara SRESID dan ZPRED dimana sumbu $\mathrm{Y}$ adalah $\mathrm{Y}$ yang telah terprediksi, dan sumbu $\mathrm{X}$ adalah residual (Y prediksi -Y sesungguhnya).

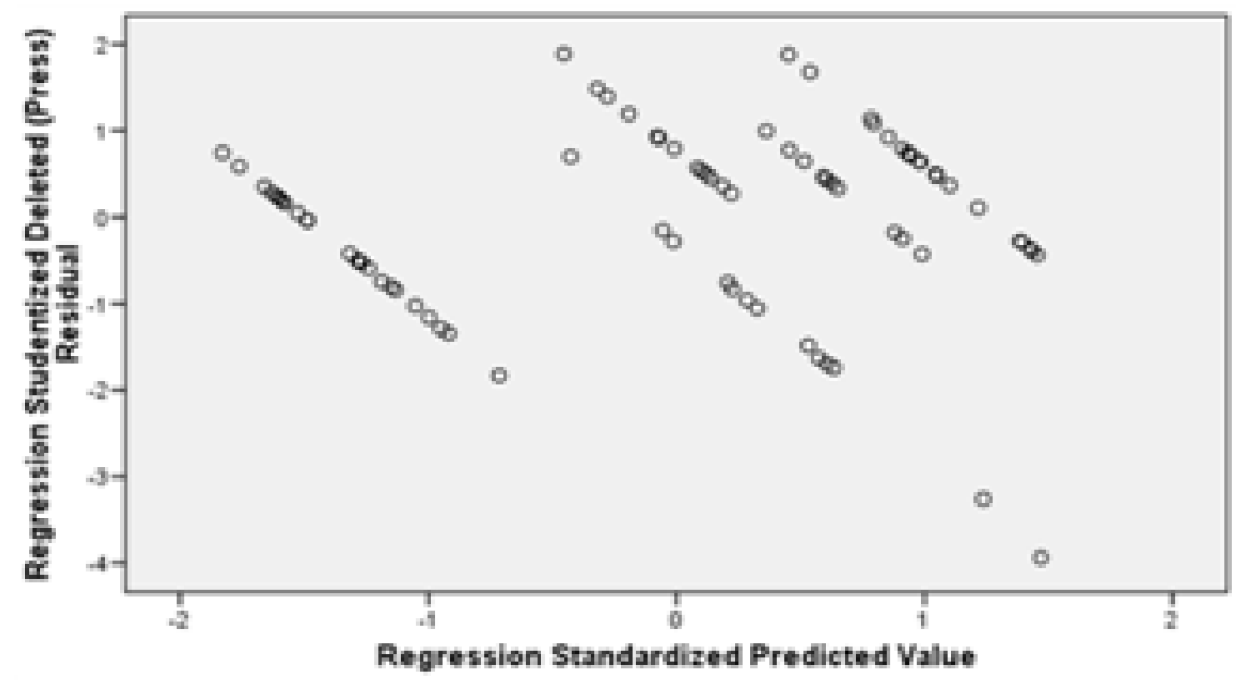

Gambar 10. Residual (Y prediksi - Y sesungguhnya).

Berdasarkan grafik scatterplot tersebut terlihat bahwa titik-titik menyebar secara acak serta tersebar baik di atas maupun di bawah angka 0 pada sumbu Y.
Dengan demikian dapat disimpulkan bahwa tidak terjadi heteroskedastisitas pada model path.

Tabel 9. Skala Jawaban Untuk Variabel Keberhasilan Proyek Y

\begin{tabular}{|c|c|c|c|c|c|c|c|c|c|c|c|}
\hline \multirow{3}{*}{$\begin{array}{c}\text { Item } \\
\text { Pertanyaan }\end{array}$} & \multicolumn{10}{|c|}{ Jawaban } & \multirow{3}{*}{ Rata-rata } \\
\hline & \multicolumn{2}{|c|}{$\mathrm{a}$} & \multicolumn{2}{|c|}{$\mathrm{b}$} & \multicolumn{2}{|c|}{$\mathrm{c}$} & \multicolumn{2}{|r|}{$\mathrm{d}$} & \multicolumn{2}{|r|}{$\mathrm{e}$} & \\
\hline & $\mathrm{f}$ & $\%$ & $\mathrm{f}$ & $\%$ & $\mathrm{f}$ & $\%$ & $\mathrm{f}$ & $\%$ & $\mathrm{f}$ & $\%$ & \\
\hline $\mathrm{Y}_{1}$ & 0 & 0,0 & 0 & 0,0 & 0 & 0,0 & 53 & 66,3 & 27 & 33,8 & 4,34 \\
\hline $\mathrm{Y}_{2}$ & 0 & 0,0 & 0 & 0,0 & 9 & 11,3 & 39 & 48,8 & 32 & 40,0 & 4,29 \\
\hline$Y_{3}$ & 24 & 30,0 & 0 & 0,0 & 3 & 3,8 & 7 & 8,8 & 46 & 57,5 & 3,64 \\
\hline
\end{tabular}

\section{Pengujian Asumsi Autokorelasi}

Uji autokorelasi adalah untuk melihat apakah terjadi korelasi antara suatu periode $t$ dengan periode sebelumnya $(\mathrm{t}-1)$. Secara sederhana adalah bahwa analisis regresi adalah untuk melihat pengaruh antara variabel bebas terhadap variabel terikat, jadi tidak boleh ada korelasi antara observasi dengan data observasi sebelumnya. Beberapa uji statistik yang sering dipergunakan adalah uji Durbin-Watson. 
Tabel 10. Pengujian Asumsi Autokorelasi

\begin{tabular}{|c|c|c|c|c|c|c|c|}
\hline No & & $\mathrm{dl}$ & $\mathrm{du}$ & 4-dl & d-dl & $\mathrm{dw}$ & Interprestasi \\
\hline 1 & Nilai & 1,544 & 1,743 & 2,257 & 2,466 & 1,788 & Tidak ada autokorelasi \\
\hline
\end{tabular}

\section{Analisis Regresi Linier Berganda}

Proses pengolahan data dengan menggunakan analisis regresi linier berganda, dilakukan beberapa tahapan untuk mencari hubungan antara variabel independen dan dependen. Berdasarkan hasil pengolahan data dengan menggunakan software SPSS didapatkan ringkasan seperti pada Tabel 11.

Variabel dependen pada analisis regresi ini adalah Y sedangkan variabel independennya adalah X1 - X4 .

Tabel 11. Ringkasan Hasil Analisis Berganda

\begin{tabular}{lcccc}
\hline Variabel & Koefisien Beta & thitung & signifikan & Keterangan \\
\hline $\mathrm{X} 1$ & 0,286 & 2,460 & 0,016 & Signifikan \\
$\mathrm{X} 2$ & 0,296 & 2,620 & 0,011 & Signifikan \\
$\mathrm{X} 3$ & 0,280 & 2,701 & 0,009 & Signifikan \\
$\mathrm{X} 4$ & 0,147 & 2,477 & 0,015 & Signifikan \\
\hline $\mathrm{A}$ & $=0,05$ & & & \\
Adjusted (R2) & $=0,831$ & & & \\
F-Hitung & $=98,427$ & & & \\
F-Tabel & $=2,494$ & & & \\
Signifikan & $=0,000$ & & & \\
t-tabel & $=1,644$ & & & \\
\hline
\end{tabular}

$$
\hat{a}_{1}=0,286
$$

Koefisien regresi ini menunjukkan bahwa terdapat pengaruh yang positif antara variabel $\mathrm{X}_{1}$ tehadap variabel $Y$, yang artinya apabila semakin tinggi tingkat pengetahuan seorang manajer proyek maka keberhasilan proyek juga akan semakin tinggi, begitu pula sebaliknya.

$$
\hat{a}_{2}=0,296
$$

Koefisien regresi ini menunjukkan bahwa terdapat pengaruh yang positif antara variabel $\mathrm{X}_{2}$ tehadap variabel $Y$, yang artinya apabila semakin baik keahlian seorang manajer proyek maka keberhasilan proyek juga akan semakin baik, begitu pula sebaliknya.

$$
\hat{a}_{3}=0,280
$$

Koefisien regresi ini menunjukkan bahwa terdapat pengaruh yang positif antara variabel $\mathrm{X}_{3}$ tehadap variabel $Y$, yang artinya apabila semakin baik komitment kerja dari seorang manajer proyek maka keberhasilan proyek juga akan semakin baik, begitu pula sebaliknya.

$$
\hat{a}_{4}=0,147
$$

Koefisien regresi ini menunjukkan bahwa terdapat pengaruh yang positif antara variabel $\mathrm{X}_{4}$ tehadap variabel $Y$, yang artinya apabila semakin baik management yang dilakukan oleh seorang manajer proyek maka keberhasilan proyek juga akan semakin baik, begitu pula sebaliknya.

\section{Penentuan Variabel yang Paling Dominan}

Untuk menentukan variabel independen yang paling berpengaruh terhadap variabel keberhasilan proyek, dapat dilakukan dengan membandingkan koefisien regresi (Beta) antara variabel yang satu dengan yang lain. Variabel independen yang paling dominan pengaruhnya terhadap varaibel keberhasilan proyek adalah variabel yang memiliki koefisien regresi yang paling besar.

Berdasarkan pada tabel yang ada tersebut dapat diketahui bahwa variabel skill/keahlian adalah variabel 
yang memiliki koefisien regresi yang paling besar. Artinya, variabel keberhasilan proyek lebih banyak dipengaruhi oleh variabel Keahlian/Skill $\left(\mathrm{X}_{2}\right)$ daripada variabel-variabel lainnya (Pengetahuan $\left(X_{1}\right)$, Komitmen/ Sikap dan Perilaku $\left(\mathrm{X}_{3}\right)$ dan Top Management $\left(\mathrm{X}_{4}\right)$. Koefisien yang dimiliki oleh variabel keahlian/ skill $\left(\mathrm{X}_{2}\right)$ bertanda positif, hal ini yang berarti semakin baik Keahlian/Skill dari seorang manajer dalam melaksanakan semua tanggung jawab dalam pekerjaannya maka semakin meningkatkan pula keberhasilan proyek yang akan diraihnya.

\section{KESIMPULAN DAN SARAN}

\section{Kesimpulan}

Berdasarkan analisis data maka dapat ditarik kesimpulan sebagai berikut:

- Secara stimultan antara variabel pengetahuan, keahlian, komitment kerja dan top management berpengaruh signifikan terhadap keberhasilan proyek sebesar 0,831 .

- Secara parsial antara variabel pengetahuan, keahlian, komitment kerja dan top management berpengaruh signifikan terhadap keberhasilan proyek yaitu masing-masing sebesar 0,286, 0,296, 0,280 dan 0,147.

- Variabel dominan yang mempengaruhi tingkat keberhasilan suatu proyek adalah skill/ keahlian.

\section{Saran}

Disarankan kepada semua manajer proyek bahwa keberhasilan mereka dalam melaksanakan suatu proyek harus mempertimbangkan faktor pengetahuan, keahlian, komitment kerja dan top management. Semakin bagus faktor-faktor tersebut akan sangat mempengaruhi kualitas hasil pekerjaan mereka.

Bagi para pimpinan perusahaan kontraktor dalam memilih manajer proyek disarankan sebaiknya memilih orang yang mempunyai skill/keahlian pada bidang atau proyek yang akan dikerjakan sehingga hasil yang didapat nantinya akan lebih berkualitas.

- Bagi seorang manajer proyek disarankan untuk menambah skill/keahlian mereka supaya mereka lebih dipercaya untuk menjalankan suatu proyek dan menghasilkan suatu produk yang berkualitas.
- Disarakan kepada masyarakat atau konsumen yang akan menggunakan jasa manajer proyek, sebaiknya dipilih dari mereka yang benar-benar memiliki skill/keahlian serta pengalaman dalam bidang tersebut.

\section{DAFTAR PUSTAKA}

Arikunto, Suharsimi, 2002, Prosedur Penelitian, PT. Rineka Cipta, Jakarta.

Boyatzis, R.E., 1982, "The competent manager: a model for effective performance". New York : Wiley.

Cleland, Irlandia , 2004, p2 Manajemen Proyek, terjemahan, Binarupa Aksara, Jakarta.

Crawford, L., 2005, "Senior Management Perceptions of Project Management Competence", International Journal of Project Management 23, pp. 7-16.

Duffield, Colin, dan Bambang Trigunarsyah, 1999, Manajemen Proyek : Dari Konsepsi Sampai Penyelesaian, University of Melbourne, Melbourne, Australia.

Gallegos, Patrick M., 1990, Mengkomunikasikan Hasil - hasil Penilaian Kinerja, dalam Kinerja, editor A. Dale Timpe, PT. Gramedia Asri Media, Jakarta.

Garvin, D.A., 1991, "How the Baldrige award really works", Harvard Business Review 69 (6), 80-95.

Heywood L, Gonczi A, Hager P., 1992, “A Guide to Development of Competency Standards for Professions", Canberra: Australian Government Publishing Service.

Love PED, Irani, Z., Edwards DJ., 2003, "Learning to reduce rework in projects: analysis of firms organizational learning and quality practices", Project Manager Journal 34(3):13-25.

Meredith, J. R., and Mantel, S. J., 2004, "Project Management A Managerial Approach 4/e" 
Published by John Wiley \& Sons, Inc, Presentation prepared by RTBM WebGroup.

Prajogo, D. I., dan Sohal, A. S., (2006), "The integration of TQM and technology/R\&D management in determining quality and innovation performance" The International Journal of Management Science Omega 34 pp. 296-312.

Spencer LMJ, Spencer SM., 1993, “Competence at Work: Models For Superior Performance”, 1st ed. New York: Wiley; 1993.

Kerzner, Harold, PhD., 1995, Project Management : A System Approach to Planning, Scheduling, and Controlling, Van Nostrand Reinhold, New York, USA.

Koolma A, dan Van de Schoot. C.J.M., 1988, Manajemen Proyek, cet. 4 , terjemahan, UIPress, Jakarta.

Leigh, Andrew, 1991, 20 Kiat Manajer yang Sukses, terjemahan, Binarupa Aksara, Jakarta.

Odusami, K.T.2002, Perception of Construction Professionals Concerning Important Skills of Effective Project Leaders, dalam The Journal of Management in Engineering, Vol 18, No. 2, April 1, 2002, ASCE.

Posner, Barry Z, 1995, What It Takes to Be a Good Project Manager, dalam Project Management : A Managerial Approach, author Jack R. Meredith and Samuel J. Mansel Jr., John Wiley \& Sons Inc., New York, USA.

Rivai, Veitzhzal, 2004, Manajemen Sumber Daya Manusia untuk Perusahaan, PT. Rajagrafindo Perkasa, Jakarta.

Rodman, T.A., 1990, Berikan Pujian Seimbang dengan Kenaikan Upah, dalam Kinerja, editor A. Dale Timpe, PT. Gramedia Asri Media, Jakarta.
Singarimbun, Masri, dan Sofian Effendi, 1989, Metode Penelitian Survey, LP3ES, Jakarta.

Snell, Scott A., dan Wexley, Kenneth N., 1990, Diagnosis Kinerja : Mengenali Penyebab penyebab Kinerja Buruk, dalam Kinerja, editor A. Dale Timpe, PT. Gramedia Asri Media, Jakarta.

Soeharto, Iman, 1997, Manajemen Proyek : dari Konseptual Sampai Operasional, cet. 3, Erlangga, Jakarta.

Sujak, Abi, 1990, Kepemimpinan Manajer, Rajawali, Jakarta.

2010. Prosedur Penelitian, Yogyakarta : Rineka Cipta. 